\title{
DEVELOPMENT OF LACTOSE FREE, FUNCTIONAL DAIRY FOODS BASED ON CONSUMER SURVEY
}

\author{
Németh $A .{ }^{1 *}$,Szabó $E^{1}{ }^{1}$, Kasza Gy. ${ }^{2}$, Ózsvári L. ${ }^{1}$ \\ 1 University of Veterinary Medicine Budapest, Hungary \\ 2 National Food Chain Safety Office, Budapest, Hungary \\ https://doi.org/10.47833/2020.1.AGR.006
}

\begin{tabular}{|c|c|}
\hline $\begin{array}{l}\text { Keyw } \\
\text { functio } \\
\text { lactose } \\
\text { consur } \\
\text { yogurt }\end{array}$ & $\begin{array}{l}\text { ry product } \\
\text { rance } \\
\text { rey }\end{array}$ \\
\hline Article & \\
\hline $\begin{array}{l}\text { Receivec } \\
\text { Revised } \\
\text { Acceptec }\end{array}$ & $\begin{array}{l}5 \text { Nov } 2019 \\
1 \text { Dec } 2019 \\
5 \text { Dec } 2019\end{array}$ \\
\hline
\end{tabular}

\section{Introduction}

Over the past nearly three decades the consumer behavior and habits of buyers in developed countries have changed drastically. On the one hand, foods that contribute to the maintenance of lifelong health and to the reduction of the damage caused by diseases of civilization are increasingly on the rise in aging societies, on the other hand with the development of health care more and more nutritional diseases are becoming evident. Understandably food and nutrition play a key role in treatment and prevention [1]. All of this creates new type of consumer expectations for the market, whether it be the price of special diet products or the willingness to pay extra cost. Functional dairy foods are innovative products in the dairy industry, and also the fastest growing segment of the dairy market [2]. Milk and milk products are almost indispensable basic foods that are an important source of most nutrients [3]. Although the first description of lactose sensitivity is from Hippocrates $400 \mathrm{BC}$, clinical symptoms have only been fully documented in the last 50 years [4]. Today, nearly $70 \%$ of the world's population suffers from hypolactasia, which often remains hidden and can lead to a lasting deterioration in quality of life [5]. Lactic acid bacteria in fermented dairy products can reduce the symptoms of lactose sensitivity, while they remain an important source of protein and calcium [6]. Increased distribution, consumption and widespread awareness-raising of functional foods can contribute to improving public health statistics [7]. Therefore, the development of lactose-free functional foods to meet the needs of consumers is one of the priority areas of the food industry today. Research shows that consumer behavior in Hungary is slowly changing, a positive trend has emerged, but the development of a robust conscious consumer base will take a long time [8]. In our research, we surveyed the Hungarian consumers' attitude to those dairy products that are meant to promote healthy diet.

\footnotetext{
* Corresponding author. Tel.: +36 709405232

E-mail address: andreanemeth93@gmail.com
} 


\section{Method}

The consumer perception of lactose-free functional foods was surveyed with a nationally representative, large element $(n=1002)$ personal questionnaire survey. Most of the questions used a closed-form, 5-point Likert scale, but there were questions where one or more of the given answers had to be selected, and there were true or false statements, and some questions had to be shortly answered. The research was conducted between July 11 and August 14, 2018 in Budapest and several rural towns. The data was recorded in a spreadsheet programme (Microsoft Office Excel) for analysis. SPSS statistical software was used to analyze the data.

$53.19 \%$ of the respondents were women and $46.81 \%$ men, $17.96 \%$ of them were under 30 years of age, $16.97 \%$ between 30 and 39 years, $34.53 \%$ between 40 and 49 years, and $30.54 \%$ over 60 years old, respectively. A significant majority $(68 \%)$ of the respondents classified themselves as "average" in terms of their financial situation. The majority of the respondents had BSc/MSc diploma $(55.20 \%)$, or high school degree $(33.30 \%)$ and only a small percentage $(11.50 \%)$ had basic education.

\section{Results and Discussion}

Milk and dairy products play major role in healthy nutrition [3] and are important part of the daily diet. Due to their probiotic and prebiotic content fermented milk products may be valuable part of a lactose-free diet [9]. The respondents had the opportunity to evaluate the role of certain foods in health preservation. Out of 25 food groups that was listed dairy products as possible "healthy foods" were ranked only 11 th and milk was only ranked 18th. According to the respondents' answers the health-preserving role of milk and dairy products is questionable for consumers and their potential role in the prevention of certain diseases is not realized.

The incidence of lactose intolerance in Europe is between 5\% and 10\% [5], but only $10.40 \%$ of the participants stated that they are indeed lactose intolerant. In Hungary the disease often stays hidden. In our research only $8.10 \%$ of the respondents saw a doctor because of their alleged illness.

Respondents were given the opportunity in the questionnaire to assess their level of concern and willingness to address specific health issues. Among the issues that concern the respondents the most we have been particularly focused on those, which can be treated and prevented with nutrition, furthermore where dairy products are scientifically proven to be beneficial. We had a particular emphasis on lactose intolerance.

$80.20 \%$ of the respondents are not affected nor worried by lactose intolerance as a possible health problem. Only $13.60 \%$ of them are concerned about the disease and would pay extra cost to prevent or treat it. In terms of the statement "I often eat lactose-free foods" the mean agreement was 2.06 on a scale 1 to 5 . The consumption of the products is medium, rather low.

With regard to the treatment of the disease the following results were obtained (Figure 1.).

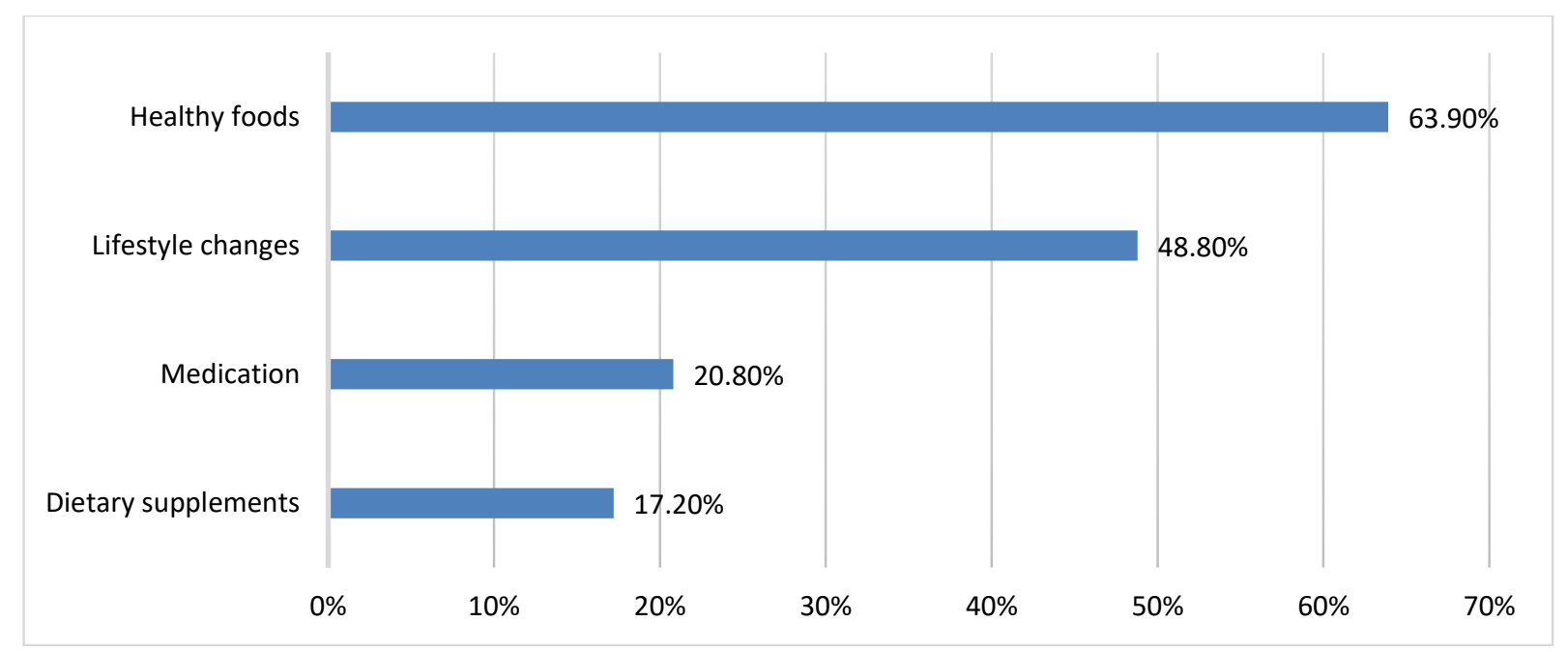

1. Figure Evaluation of the treatment and prevention of lactose sensitivity 
The answers reveal the lack of knowledge. There are three forms of lactose intolerance. The first form, which is the congenital form, is extremely rare. The secondary lactose intolerance is genetic and more frequent, while the third one is often a consequence of other underlying gastrointestinal disease and can be related to antibiotic therapy or lifestyle [5].

Lactose intolerance cannot be treated with drugs. However, every fifth respondent believed that there was medication that could help to prevent or cure the disease. There is the possibility that lactase-enzyme tablets, which are already available in most places and which are considered to be medicinal foods, are mistakenly known as medicines by the general public.

Unfortunately, the absence of appropriate knowledge often causes the complete exclusion of dairy products for the consumers who diagnosed themselves through self-diagnosis. Such an absence of dairy products may in the long run create the risk of developing deficiency diseases and one of the most serious consequences may be osteoporosis [3].

Consuming "healthy foods" can contribute to maintaining a normal intestinal flora and preventing the development of secondary lactose intolerance, which often the results of poor lifestyle but genetic intolerance cannot be prevented by eating only "healthy foods".

One of the most widely consumed functional dairy products in the world is yogurt [10]. As it was previously discussed yogurt was ranked by the respondents only in the middle of the list of potentially health-promoting foods. The vast majority $(83.90 \%)$ of those completing the questionnaire consume yogurt and also buy it (83.50\%). Yogurt is an important source of pro- and prebiotic bacteria as a fermented dairy product, so it can be appropriately included in a lactose intolerant diet [9]. The survey participants were given the opportunity to comment on the price of normal and lactosefree small-pot yogurt. Based on the results in case of the statement "... HUF/pot is a good deal for normal and a ....HUF/pot is a good deal for a lactose free yogurt" consumers put the price of a normal yogurt in lower price-range around 100.98 HUF/pot and are willing to pay an average of about $136.26 \mathrm{HUF} /$ pot for the lactose-free version. Thus, the consumers are willing to pay $34.94 \%$ more (+35.28 HUF/pot) for lactose-free yogurt compared to normal yogurt.

No general conclusion can be drawn after analyzing the results based on the question of willingness to pay extra price. On average, the respondents agreed with the statement "I am willing to pay more for "healthy food" at $3.95(\mathrm{~S}=1.037)$. For the phrase "The price of the food is the most important aspect when I purchase", we got a value of 2.98 , ( $\mathrm{S}=1.086)$. As we have previously stated, only $13.60 \%$ of the respondents would take extra cost of treating lactose intolerance.

\section{Conclusions and recommendations}

It can be said that consumers are becoming more and more aware of the importance of nutrition in maintaining health but there is still a significant lack of knowledge to help them make good decisions. The decline in the consumption of milk and dairy products is significant and they are often judged poorly by consumers. Consuming milk as part of a healthy diet has undeniable positive physiological effects. It is not advisable to exclude or completely exclude this group of foods even for those who are lactose intolerant, especially as they may be an integral part of the treatment of the disease. Unfortunately, only a few people use medical test to detect possible lactose intolerance. A targeted presentation of these test could assist in the detection of undiagnosed lactose intolerances.

In the case of lactose intolerance more people choose not to consume dairy products when they are experiencing unpleasant symptoms and it is usually because of their lack of knowledge. This decision can lead them to new deficiency diseases, weakened immune systems and the threat of osteoporosis. Furthermore, these symptoms may even lead to aversion towards milk and dairy products, thus impairing their judgment. According to our results, the consumption of lactose-free products is low, presumably because of their higher price compared to conventional dairy products. Research shows, that although shopping habits are clearly changing, Hungarian consumers are still more likely to be price sensitive [11]. For this reason, it may be necessary to credibly increase the awareness of affected consumers, so that they can still feel justified in purchasing products despite the extra costs. 


\section{Acknowledgment}

The Project was supported by the European Union and co-financed by the European Social Fund: (1) EFOP-3.6.1-16-2016-00024 'Innovations for Intelligent Specialisation on the University of Veterinary Science and the Faculty of Agricultural and Food Sciences of the Széchenyi István University Cooperation'; (2) EFOP-3.6.2-16-2017-00012 'Development of a product chain model for functional, healthy and safe foods from farm to fork based on a thematic research network'; and (3) EFOP-3.6.3-VEKOP-16-2017-00005 'Strengthening the scientific replacement by supporting the academic workshops and programs of students, developing a mentoring process'.

\section{References}

[1] Szakály, Z., Kiss, M., Jasák, H.,2014: Functional foods, consumer attitudes and personalized nutrition. The Hungarian Journal of Nutrition Marketing, 1. 1-2. p. 3-17.

[2] Lehota, J., Komáromi, N., 2007: Some questions of research methodology on consumer behaviour in consumption of functional foods. Acta Oeconomica Kaposcáriensis, 1. 1-2. p. 67-81

[3] Nagpal, R., Behare, P. V., Kumar, M., Mohania, D., Yadav, M., Jain, S., Menon, S., Parkash, O., Marotta, F., Minelli, C., Henry, C. J. K., Yadav, H., 2014: Milk, Milk Products, and Disease Free Health: An Updated Overview. Critical Reviews in Food Science and Nutrition, 52. p. 321-333

[4] Matthews, S.B., Waud, J.P., Roberts, A.G.,Campbell, A.K,.2005: Systemic lactose intolerance: a new perspective on an old problem, Postgrad Med, 81 p. 167-73

[5] Lomer, M. C. E., Parkes, G.C., Sanderson, J. D., 2007: Review article: lactose intolerance in clinical practice -myths and realities. Alimentary Pharmacology \& Therapeutics, 27. p. 93-103

[6] Kenjeric, D., Nieder, D., Stokanovic, M. C., Flanjak, I., 2016: Assesment of fermented dairy products adequacy in diet of lactose intolerant persons, Food in Health and Disease, scientific-professional journal of nutrition and dietetics, 5 (1) p. 1-5

[7] Németh-T., A., Vincze-Tóth, J., Hegyi, J., Troján, Sz., 2013: A funkcionális élelmiszerek potenciális fogyasztói és vásárlói csoportjainak felmérése, Gazdálkodás, 57. (6) p. 579-587

[8] Deák, Zs., 2014: Fenntarthatóság és a fogyasztói társadalom Magyarországon, GRADUS 1. (2), p. 126-132

[9] Shaukat, A., Levitt, M. D., Taylor, C. B., MacDonald, R., Shamliyan, T. A., Kane, R. L., Wilt, T. J., 2010: Systematic Review: Effective Management Strategies for Lactose Intolerance. Annals of Internal Medicine, 152. p. 797-803

[10] Kurien, A., Puniya, A., Singh, K., 2005: Selection of a prebiotic and Lactobacillus acidophilus for synbiotic yoghurt preparation. Indian Journal of Microbiology, 45. 45-50.

[11] Deák, Zs., 2017: Understanding and use of food labeling in Hungary, GRADUS 4. (2), p. 146-149 